\title{
Assessment and Characterization of Macronutrient in Soil of Kabeerdham District, Chhattisgarh, India
}

\author{
Kavita Chandravanshi*, Narendra Swaroop, and Tarence Thomas \\ Department of Soil Science and Agriculture Chemistry, Sam Higginbottom University of \\ Agriculture, Technology and Sciences - Prayagraj 211 007, U.P., India \\ *Corresponding author
}

\begin{tabular}{|l|}
\hline Ke y w o r d s \\
Kabeerdham \\
district, Chemical \\
properties, Soil, \\
Depths
\end{tabular}

A B S T R A C T
A survey of chemical properties of soil samples were collected from 3 Blocks. They are Kawardha, Bodla and Lohara in Kabeerdham District, Chhattisgarh was carried out in 2019-20.The main objective of this study was to collect information regarding soil chemical status, for 9 sampling points were selected. Soil samples were collected at a depth of $0-15 \mathrm{~cm}$ and $15-30 \mathrm{~cm}$ and soil sample analysed for soil $\mathrm{pH}$, Electrical conductivity, organic carbon and Nitrogen, Phosphorus and potassium. The value of $\mathrm{pH}$, Electrical conductivity, organic carbon is found in ranges from $7.00-8.30$, $0.21-0.65 \mathrm{dsm}^{-1}, 0.16-0.70 \%$ respectively. and Nitrogen, Phosphorus, potassium is found in ranges from $150.50-313.60\left(\mathrm{~kg} \mathrm{ha}^{-1}\right), 10.03-22.11(\mathrm{Kg}$ $\left.\mathrm{ha}^{-1}\right)$ and 240-507.69 $\left(\mathrm{kg} \mathrm{ha}^{-1}\right)$ respectively. The $\mathrm{pH}$ is neutral to slightly alkaline, Electrical conductivity is normal. The status of organic carbon percent and nitrogen is low to medium, the status of phosphorus and potassium is medium to high.

\section{Introduction}

Chhattisgarh state is known as "Rice bowl of India". The state is mono cropped mainly with rice but this cropping system is threatening the sustainability of the system (Kumar et al., 2019). Leaching causes nutrient stresses in soil specially with more agricultural practices (Havlin et al., 1999). Agricultural production might not be sustainable unless major steps are taken to improve management of crop residue by adopting conservation agriculture (Pretty et al., 2011). Soil is the basic resource for agriculture and its proper management is essential to sustain agricultural production and soil productivity. Soil testing is one of the best available tools, to ascertain the physical characteristics \& nutrient status of a field so as to assess the fertilizer requirement for a crop or a cropping system or for knowing the reclamation requirements for a crop or a 
cropping system or for knowing the reclamation requirement if the soil is saline or sodic in nature fertilizer application based on soil test is the best available approach for harvesting the economically viable potential yields of crops by increasing input use efficiency and maintaining soil health (Singh and Brar, 2005).

Nitrogen is important for growth because it is a major part of all amino acids, which are the building blocks of all proteins, including the enzymes, which control virtually all biological processes.a good supply of nitrogen stimulates root growth and development, as well as the uptake of other nutrient. Plants deficient in nitrogen tend to have a pale yellowish green color (chlorosis), have a stunted appearance, and develop thin, spindly stems (Brady and well, 1999). Phosphorus has been called the "master key to agriculture" Because low crop production is attributed mainly due to lack of phosphorus than the deficiency of other Elements except nitrogen. Phosphorus enhance many aspects of plant physiology, including the fundamental process of photosynthesis, nitrogen fixation, flowering, fruiting, (including seed production), and maturation. Root growth, particularly development of lateral roots and fibrous rootlets, is encouraged by phosphorus (Singh et al., 2018). Phosphorus - deficient plant is usually stunted, thin-stemmed, and spindly, but its foliage is often dark, almost bluish, green. Thus, unless much larger, healthy plants are present to make a comparison, phosphorus deficient plants often seem quite normal in appearance. In severe cases, phosphorus deficiency can cause yellowing and senescence of leaves (Brady and Weil, 1999). Phosphorus is usually plant- available in soil as inorganic phosphate ions $\left(\mathrm{HPO}_{4}{ }^{2-}\right.$ and $\mathrm{H}_{2} \mathrm{PO}_{4}{ }^{2-}$ ) and sometimes as soluble organic phosphorus. The $\mathrm{HPO}_{4}{ }^{2-}$ anion dominates in strongly acidic soils while the $\mathrm{H}_{2} \mathrm{PO}_{4}{ }^{-}$anion dominates in alkaline soils. Both anions are important in near-neutral soils (Rao et al., 2016).

The original sources of potassium are the primary minerals, such as micas (biotite and muscovite) and potassium feldspar (orthoclase and microcline). As these minerals weather (Rao et al., 2019) potassium exists in $\mathrm{k}^{+}$from and its function appears to be catalytic in nature. Potassium enhances the synthesis and translocation of carbohydrates, there by encouraging cell wall thickness and stalk strength. The deficiency symptom are quite characteristic on may plants as a yellowing and eventually death of leaf margins for alfalfa, white spots first appear along leaf margins followed by a coalescing of the spots to give a, marginal edge effect. The dying of the edges of older leaves is commonly called necrosis (Brady and Weil, 1999).

The production of rice crop is more in the central part of India. Chhattisgarh is situated in the central part of India.The state of Chhattisgarh, with Raipur as its capital, came into existence on $1^{\text {st }}$ November, 2000 by separation of 16 districts of Chhattisgarh region from Madhya Pradesh. At present 28 districts are there in Chhattisgarh. Chhattisgarh is situated between $21.2787^{\circ} \mathrm{N}$ latitude and $81.8661^{\circ} \mathrm{E}$ longitude in central eastern part of India. The total geographical area of the state is 136.03 thousand sq.km.

Geographically, Chhattisgarh is divided into three district land areas viz.,

Chhattisgarh Plains, Bastar Plateau and Northern Hill Zones.

The state receives annual rainfall ranging from less than $1200 \mathrm{~mm}$ to greater than 1600 $\mathrm{mm}$ in different areas. Paddy is main crop of 
the state and due to abundance of production of paddy Chhattisgarh was known a 'Rice bowl of central India.'

A vast region of Chhattisgarh is covered by red and yellow soil. There are a number of types of soil found in Chhattisgarh area but there are four major types namely Kanhar, Matasi, Doesa and Bhata, which cover major portion of the total land area. The red color of soil is generally related to anhydrate ferric oxide, and partially hydrated ions oxides. The yellow color in soil is also due to oxides of iron. The soil of region are deficient in important mineral nutrient like nitrogen, phosphorous, lime and potash.

The investigation to evaluate the fertility status of black soil in different village of Kabeerdham district of Chhattisgarh State. Two types of soil are present namely Alfisols and Vertisols comes under black soil. These two types soil have been taken for systematic survey under study.

The information of surveyed area and other details are presented in the following sections. It is located $21.32^{\circ}$ North latitude, $80.28^{\circ}$ East longitude with an altitude of $280 \mathrm{~m}$ above rainfall 1241.0. The region generally experiences hot, sub humid climate, having average rainfall of $1157.1 \mathrm{~mm}$. The Vertisols group of the soil covered under the different villages of the kabeerdham district in Chhattisgarh has been taken for fertility evaluation on various aspects (Kumar et al., 2014).

\section{Materials and Methods}

The present entitled Assessment and characterization in soil of Kabeerdham district, Chhattisgarh was conducted in three stages i.e. soil survey and mapping, collection of sample and their analysis for different soil parameters.

\section{Location}

Kabeerdham district is one of the 28 administrative district of Chhattisgarh state in central India. It is one among the 4 bolcks of Kabeerdham. The district is divided into four blocks Kabeerdham, Bolda, sahaspur Lohara and Pandariya. Each Blocks is a single block of same name. The two Vidhan Sabha constituencies in this district are Kawardha and Pandariya (Fig. 1). The district is located at $21^{\circ} 14^{\prime} \mathrm{N} 80^{\circ} 48^{\prime} \mathrm{E}$ to $22.28^{\circ} \mathrm{N} 81.42^{\circ} \mathrm{E}$. It is covers an area of $4,447.5 \mathrm{~km}^{2}$. Plain zone is the south-east part of Chhattisgarh, from where the soil has been taken for analysis.

\section{Climate and Weather}

The climate is tropical in kawardha. when compared with winter, the summer have much more rainfall. The koppen- Geiger climate classification is in kawardha, the average annual temperature is 26.0 . About $1090 \mathrm{~mm}$ of precipitation falls annually. weather forecasting of rain, sun, wind, humidity and temperature kawardha is $347 \mathrm{~m}$ above sea level. Heavy rain and pounding surf in the north-eastern United States.

\section{Soil sampling and preparation for laboratory work}

The 18 soil samples were collected from 3 different blocks (1) kabeerdham, Bano $\left(\mathrm{V}_{1}\right)$, Daujri $\left(\mathrm{V}_{2}\right)$, and Dharampura $\left(\mathrm{V}_{3}\right)$, (2) Bodla, Podi $\left(\mathrm{V}_{4}\right)$, Sarodha $\left(\mathrm{V}_{5}\right)$, and Manikpur $\left(\mathrm{V}_{6}\right)$, (3) sahaspur Lohara, Achankpur $\left(\mathrm{V}_{7}\right)$, and Odiyakalan $\left(\mathrm{V}_{8}\right)$, Singarpur $\left(\mathrm{V}_{9}\right)$ it different depths $(0-15$, and $15-30 \mathrm{~cm})$ with the help of spade and khurpi. The soil $\mathrm{pH}$ was determined in 1:2 Soil water suspensions with the help of digital electrical $\mathrm{pH}$ meter (Jackson, 1958). The electrical conductivity measured of soil water suspension by using electrical conductivity meter (Wilcox, 1950). The instrument was calibrated with $0.01 \mathrm{M}$ standard $\mathrm{KCl}$ solution at $25^{\circ} \mathrm{C}$. Organic 
carbon was determined by Rapid Titratin Method (Walkley and Black, 1947).

Available nitrogen was determined by using alkaline potassium permanganate method as given by (Subbiah and Asija, 1956). The Phosphorus is extracted from soil by $0.5 \mathrm{M}$ $\mathrm{NaHCO}_{3}(\mathrm{pH}$ 8.5). phosphorus in the soil extract is determined calorimetrically using a photoelectric colorimeter after developing molybdenum blue colour. Olsen colorimetric method (1954). The exchangeable potassium is extracted from $2 \mathrm{~N} \mathrm{NH}_{4} \mathrm{OAC}(\mathrm{pH} \mathrm{7.0)}$ and potassium was determined by flame photometer (Table 1).

\section{Results and Discussion}

\section{Soil pH}

The lowest value of $\mathrm{pH}$ found in singarpur $\left(\mathrm{V}_{9}\right)$ at depths $(0-15$ and $15-30 \mathrm{~cm}) 7.00$ and highest value in Daujri $\left(\mathrm{V}_{2}\right)$ at depth (15$30 \mathrm{~cm}) 8.30$. The $\mathrm{pH}$. at different villages and depths was found to significant (Table 2 and Fig. 2).

\section{Electrical conductivity (EC) $\mathrm{dsm}^{-1}$}

The lowest value of electrical conductivity found in Pondi $\left(\mathrm{V}_{4}\right)$ at depth $(0-15 \mathrm{~cm}) 0.21$ $\mathrm{dsm}^{-1}$ and highest value in Daujri $\left(\mathrm{V}_{2}\right)$ at depths $(15-30 \mathrm{~cm}) 0.65 \mathrm{dsm}^{-1}$. The Electrical conductivity was found to be significant at different villages but non-significant at different depths (Fig. 3).

\section{Organic carbon (OC) \%}

The lowest value of organic carbon percent is found in soil of odiya kla $\left(\mathrm{V}_{8}\right)$. At depth (15$30 \mathrm{~cm}) 0.16$ percent. and highest value in soil of Daujri $\left(\mathrm{V}_{2}\right)$ at depths $(0-15 \mathrm{~cm}) \quad 0.70$ percent. The OC was found to be significant at different villages but non-significant at different depths (Fig. 4).

\section{Available nitrogen $\left(\mathrm{kg} \mathrm{ha}^{-1}\right)$}

The lowest value of nitrogen is found in soil of Pondi $\left(\mathrm{V}_{4}\right)$. at depths $(0-15 \mathrm{~cm}) 150.50 \mathrm{~kg}$ $\mathrm{ha}^{-1}$. and highest value in soil of Achankpur $\left(\mathrm{V}_{7}\right)$ at depths $(15-30 \mathrm{~cm}) 313.60 \mathrm{~kg} \mathrm{ha}^{-1}$. The available nitrogen $\left(\mathrm{kg} \mathrm{ha}^{-1}\right)$ was found to be significant at different villages but nonsignificant at different depths.

\section{Available phosphorus $\left(\mathrm{kg} \mathrm{ha}^{-1}\right)$}

The lowest value of nitrogen is found in soil of Singarpur $\left(\mathrm{V}_{9}\right)$ at depths $(15-30 \mathrm{~cm})$ $10.03 \mathrm{~kg} \mathrm{ha}^{-1}$ and highest value in soil of Srodha $\left(\mathrm{V}_{5}\right)$ at depths $(0-15 \mathrm{~cm}) 22.11 \mathrm{~kg} \mathrm{ha}^{-1}$. The available phosphorus $\left(\mathrm{kg} \mathrm{ha}^{-1}\right)$ was found to be significant at different villages but nonsignificant at different depths.

\section{Available Potassium (kg ha $\left.{ }^{-1}\right)$}

The lowest value of $\mathrm{K}$ is found in soil of Bano $\left(\mathrm{V}_{1}\right)$.and Sarodha $\left(\mathrm{V}_{5}\right)$ at depths $(15-30 \mathrm{~cm})$ $240 \mathrm{~kg} \mathrm{ha}^{-1}$. and highest value in soil of Achankpur $\left(\mathrm{V}_{7}\right)$ at depths $(0-15 \mathrm{~cm}) 507.69 \mathrm{~kg}$ $\mathrm{ha}^{-1}$. The available potassium $\left(\mathrm{kg} \mathrm{ha}^{-1}\right)$ at different villages and depths was found to significant.

It can be concluded that the soil of kawardha block in kabeerdham district of Chhattisgarh showed status according to (Table 3) the value of $\mathrm{pH}$ is found varied from 7.00-8.30.it is neutral to slightly alkaline in nature, similarly result reported by (Dameshwar and Mamta (2018). The Electrical conductivity valve is varied from $0.21-0.65 \mathrm{dsm}^{-1}$ and it is normal. Similarly results found (kumar et al., 2017). The value of organic carbon percent is found in varied from $0.16-0.70 \%$ and this is low to medium level. Similarly result reported by (Prasad et al., 2017). The value of available nitrogen $\left(\mathrm{Kg} \mathrm{ha}^{-1}\right)$ is found in varied from $150.50-313.60\left(\mathrm{~kg} \mathrm{ha}^{-1}\right)$ is low to medium level. Similar result reported by (singh et al., 2018). 
Table.1 Salient soil properties of study area

\begin{tabular}{|l|l|l|}
\hline Soil characteristics & Range & Mean \\
\hline pH & $7.00-8.30$ & 7.58 \\
\hline $\mathbf{E C}\left(\mathbf{d s m}^{-\mathbf{1}}\right)$ & $0.21-0.65$ & 0.37 \\
\hline O.C.\% & $0.16-0.70 \%$ & 0.42 \\
\hline Available N $\left(\right.$ kgha $\left.^{-\mathbf{1}}\right)$ & $\begin{array}{l}150.50- \\
313.60\end{array}$ & 225.13 \\
\hline $\begin{array}{l}\text { Available P } \\
\text { (kgha }\end{array}$ & $10.03-22.11$ & 14.87 \\
\hline Available K $\left(\right.$ kgha $\left.^{-1}\right)$ & $240-507.69$ & 340.59 \\
\hline
\end{tabular}

Table.2 Rating for soil test values and their nutrient indices based on the specific rating chart modified from Brajendra et al., (2014)

\begin{tabular}{|c|c|c|c|c|}
\hline Soil property & Unit & & Range & \\
\hline Soil pH & $\mathrm{pH}$ unit & $<6.0$ (Acidic) & 6.1-8.0 (Neural) & $>8.0$ (Alkaline) \\
\hline $\begin{array}{l}\text { Electrical } \\
\text { conductivity }\end{array}$ & $\mathrm{dsm}^{-1}$ & $<1.0$ (Normal) & 1.0-2.0 (Critical) & $>2.0$ (Injurious) \\
\hline Organic carbon & Percent & $<0.5$ (Low) & $0.5-0.20$ (Medium) & $>0.75$ (High) \\
\hline Avalible nitrogen & $\mathrm{Kg} \mathrm{ha}^{-1}$ & $<280$ (Low) & 280-560 (Medium) & $>560$ (High) \\
\hline $\begin{array}{l}\text { Avalible } \\
\text { phosphorus }\end{array}$ & $\mathrm{Kg} \mathrm{ha}^{-1}$ & $<10$ (Low) & 10-25 (Medium) & $>25$ (High) \\
\hline Avalible potassium & $\mathrm{Kg} \mathrm{ha}^{-1}$ & $<110$ (Low) & 110-280 (Medium) & $>280$ (High) \\
\hline
\end{tabular}

Table.3 Analysis result Available Nitrogen $\left(\mathrm{kg} \mathrm{ha}^{-1}\right)$, phosphorus $\left(\mathrm{kg} \mathrm{ha}^{-1}\right)$, Potassium $\left(\mathrm{kg} \mathrm{ha}^{-1}\right)$ of soil sample of kabeerdham District.Chhattisgarh.at $(0-15 \mathrm{~cm}, 15-30 \mathrm{~cm})$ depths

\begin{tabular}{|l|c|c|c|c|}
\hline Village & $\begin{array}{c}\text { Depth } \\
\text { of cm }\end{array}$ & $\begin{array}{c}\text { Available } \\
\text { nitrogen } \\
\left(\mathbf{k g ~ h a}^{-1}\right)\end{array}$ & $\begin{array}{c}\text { Available } \\
\text { phosphorus } \\
\left(\mathbf{k g ~ h a}^{-1}\right)\end{array}$ & $\begin{array}{c}\text { Available } \\
\text { potassium } \\
\left(\mathbf{k g ~ h a}^{-1}\right)\end{array}$ \\
\hline $\begin{array}{l}\text { Bano } \\
\left(\mathbf{V}_{\mathbf{1}}\right)\end{array}$ & $0-15$ & 1.25 & 2.00 & 66.66 \\
\hline $\begin{array}{l}\text { Daujri } \\
\left(\mathbf{V}_{\mathbf{2}}\right)\end{array}$ & $15-30$ & 1.25 & 1.60 & 62.06 \\
\hline Dharampura & $0-15$ & 1.17 & 2.50 & 73.52 \\
\hline$\left(\mathbf{V}_{\mathbf{3}}\right)$ & $15-30$ & 1.17 & 2.83 & 70.00 \\
\hline Pondi & $0-15$ & 1.17 & 2.83 & 66.66 \\
\hline$\left(\mathbf{V}_{\mathbf{4}}\right)$ & $15-30$ & 1.25 & 2.66 & 64.28 \\
\hline Sarodha & $0-15$ & 1.25 & 2.00 & 63.00 \\
\hline$\left(\mathbf{V}_{5}\right)$ & $15-30$ & 1.17 & 2.83 & 59.11 \\
\hline $\begin{array}{l}\text { Manikpur } \\
\left(\mathbf{V}_{\mathbf{6}}\right)\end{array}$ & $0-15$ & 1.25 & 2.28 & 64.28 \\
\hline $\begin{array}{l}\text { Achankpur } \\
\left(\mathbf{V}_{\mathbf{7}}\right)\end{array}$ & $15-30$ & 1.25 & 2.66 & 62.33 \\
\hline $\begin{array}{l}\text { Odiyakalan } \\
\left(\mathbf{V}_{\mathbf{8}}\right)\end{array}$ & $0-15$ & 1.17 & 2.83 & 62.06 \\
\hline $\begin{array}{l}\text { Singarpur } \\
\left(\mathbf{V}_{\mathbf{9}}\right)\end{array}$ & $0-15$ & 1.17 & 2.42 & 60.33 \\
\hline & $15-30$ & 1.17 & 2.83 & 66.66 \\
\hline & $15-30$ & 1.11 & 2.57 & 63.01 \\
\hline
\end{tabular}


Fig.1 Map of Kabeerdham District

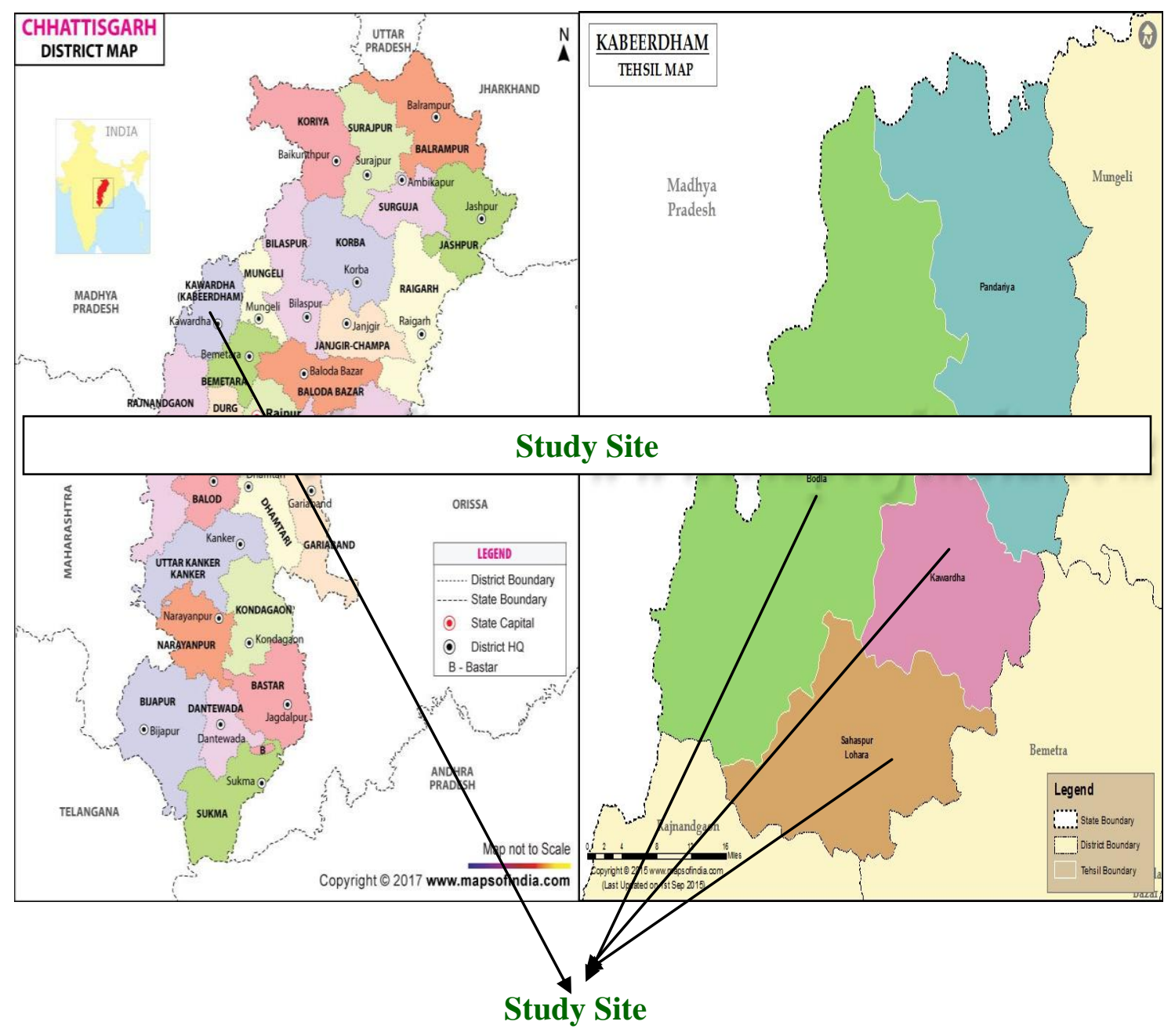

Fig.1 pH of soil samples at different depth (0-15, and 15-30 cm) of kabeerdham District

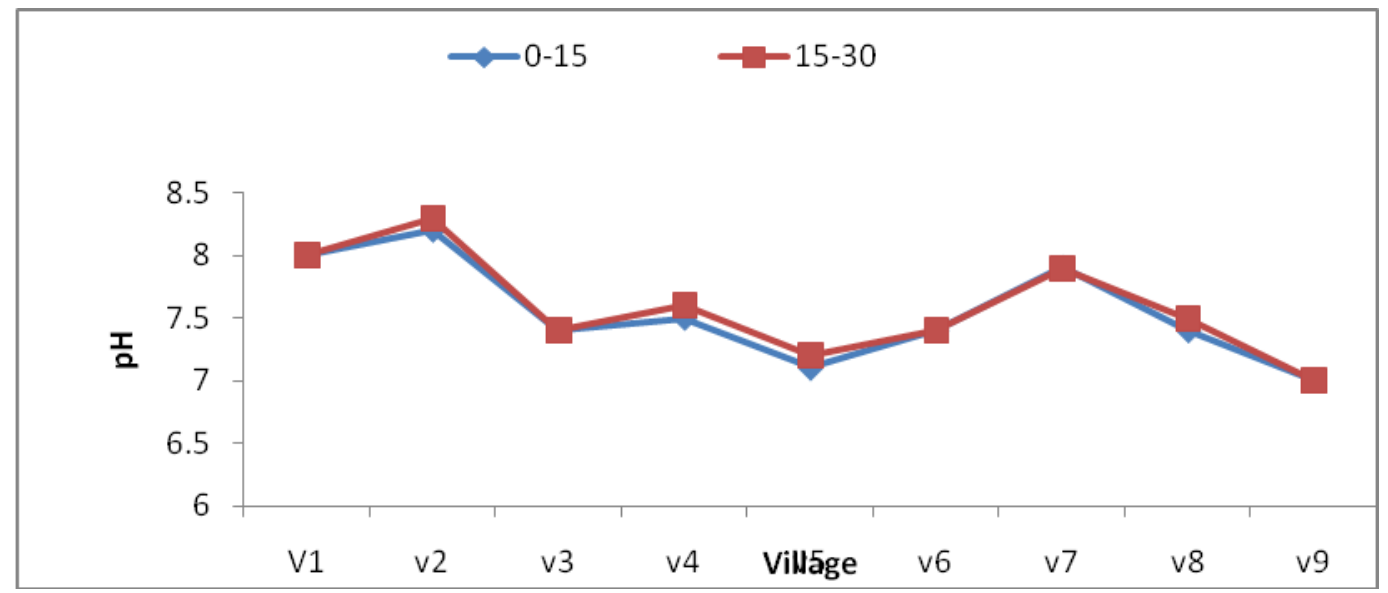


Fig.2 Electrical conductivity of soil samples at different depth $(0-15$ and $15-30 \mathrm{~cm})$ of Kabeerdham District

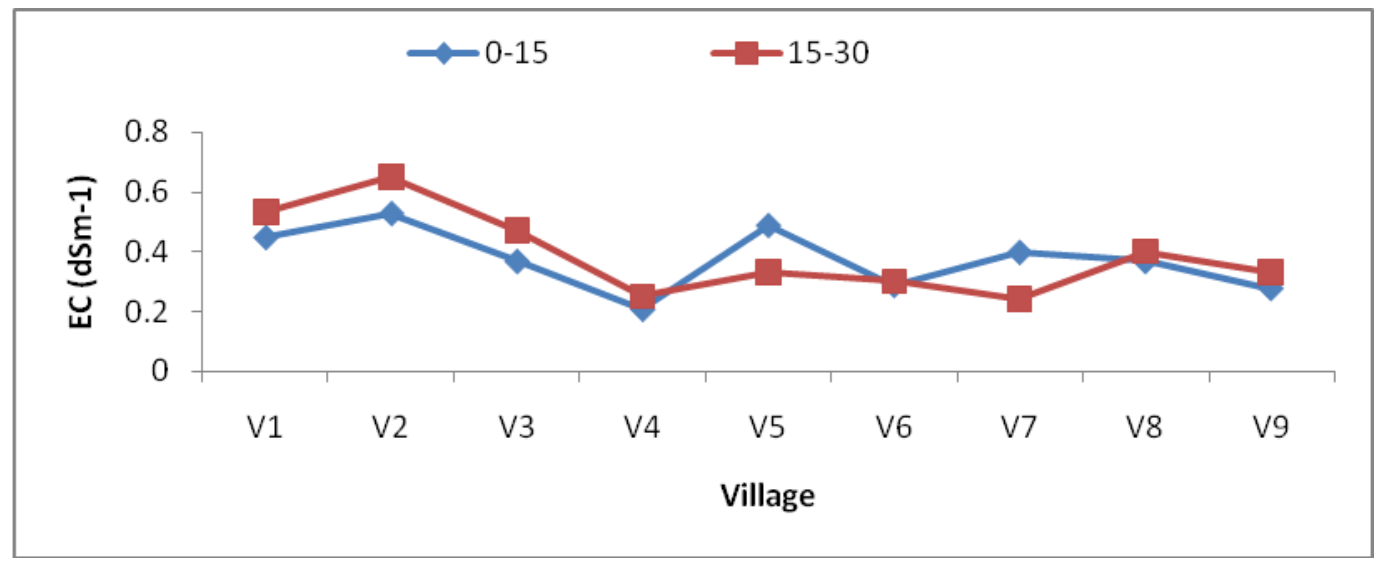

Fig.3 Organic carbon (\%) of soil samples at different depth $(0-15$ and $15-30 \mathrm{~cm})$ of kabeerdham District

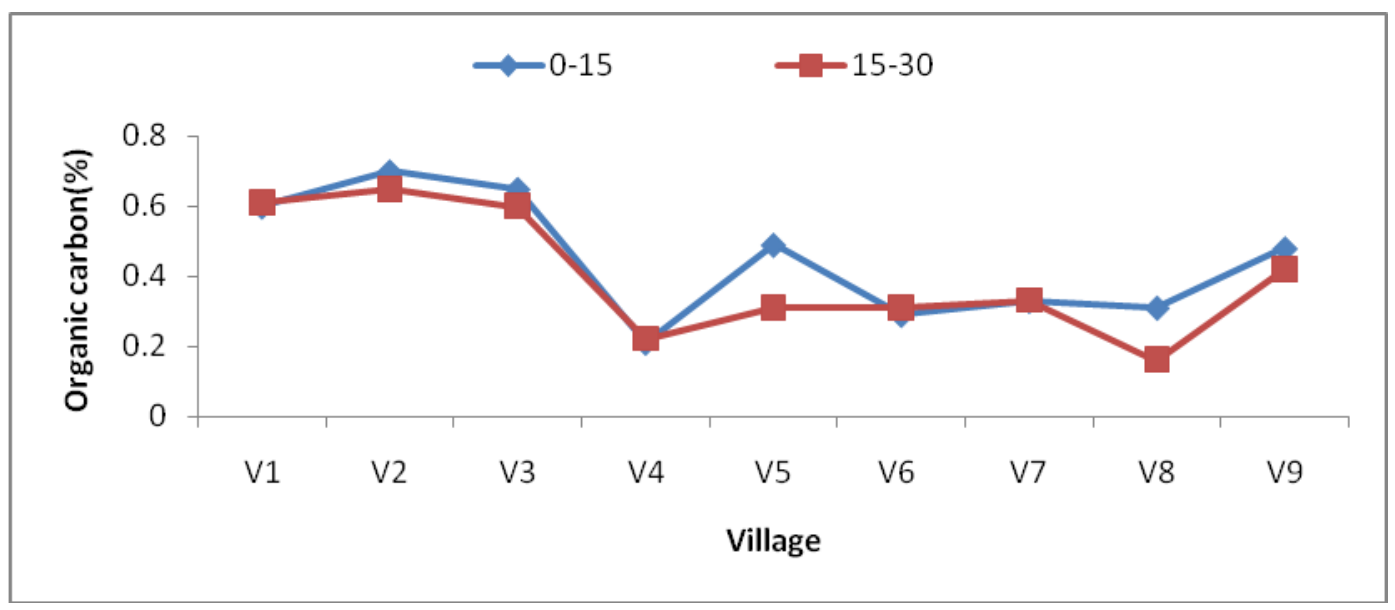

The value of Available phosphorus $\left(\mathrm{Kg} \mathrm{ha}^{-1}\right)$ is found in varied from10.03-22.11( $\left.\mathrm{Kg} \mathrm{ha}^{-1}\right)$ is medium level. Similar result reported by (Kumar et al., 2017). The value of Available potassium $\left(\mathrm{Kg} \mathrm{ha}^{-1}\right)$ is found in varied from 240-507.69 $\left(\mathrm{kg} \mathrm{ha}^{-1}\right)$ is medium to high level. Similarly result reported by (Rao et al., 2016). The $\mathrm{pH}$ is due to production of acids by bacterial action in aerobic or nitrification process taking place in the soil. The low EC may be good drainage condition. Maximum nitrogen available content was observed to be in surface horizon and decrease with depth. However the highest phosphorus content was observed in the surface horizon and decreased with depth. The highest $\mathrm{K}$ content was observed in the surface horizons and showed more or less decreasing trend with depth this may be more intense weathering, release of $\mathrm{K}$ from organic residue.

\section{Acknowledgement}

Authors are sincerely thankful to Dr. Narendra Swaroop, Associate Professor, Department of soil science and Agricultural chemistry. Dr. Tarence Thomas, Professor and Head, Department of Soil Science and Agriculture Chemistry and Dr David AA. Associate Professor, Department of soil 
science and Agricultural chemistry, Sam Higginbottom University of Agriculture, Technology and Scinces, Allahabad.

\section{References}

Black, C.A. (1965). Method of soil analysis 1. American Society of Agronomy. Madison, Wisconsin, USA.

Brady, N.C. and Weil, R.R. (1996) The nature and properties of soil (11th ed.) prentice Hall, New York. 1996.

Brajendra, Latha, p. c., Surekha, K., Prasad Babu, M.B.B., Ghosh, T.J. and Bhadana, V. B. (2014). Soil health testing manual. Parma publishers and distributors, India.

Dameshwar, Mamta and MO Navaz. (2018).soil fertility status of kosadol block under Balodabajar district of Chhattisgarh, International Journal of chemical studies. 6(2): 38- 41

Jackson, M.L. (1958). Soil Chemical Analysis, prentice Hall of IndianPrivate Limited, New Delhi.

Kumar, A., Mishra, V. N., Srivastav, L.K., and Banwasi, R. (2014). Evaluation of soil Fertility Status of Available Major Nutrient (N, $\mathrm{P}$ and $\mathrm{K}$ ) and Micro Nurient (Fe, $\mathrm{Mn}, \mathrm{Cu}$, and $\mathrm{Zn}$ ) in Vertisol of Kabeerdham District of Chhattisgarh, India International Journal of Interdisciplinary and Multidisciplinary Studies (IJIMS) (1) 10 72-79.

Olsen, S. R., Cole, C.V., Watnahe, F. S. And Dean, L. A. (1954). Estimation of available phosphorus is soil by extraction with sodium bicarbonate USDA Circular. 939.

Prasad D., Swaroop N., Thomas T., David A.A. and Rao P.S. (2017). Assessment and Characterization of Soil of Kabeerdham District, Chhattisgarh, India, International Journal of Current Microbiology and Applied Sciences
6(6): 1378-1384

Pretty and Zareen pervez Bharucha (2014), Sustainable intensification in agricultural systems. U.S. of Essex. Wivenhoe park. Colchester 1-26.

Rao, P.S., Tarence Thomas, Amit Chattree, Joy Dawson and Narendra Swaroop (2019), Soil Chemical Properties of Bastar District, Chhattisgarh, India, International Journal of Current Microbiology and Applied Sciences 8(4): 2185-2197.

Subhiah, B. V. and Asija, C. L. (1956). A rapid procedure for the estimation of available nitrogen in soil current sci. 25 259-260

Singh, R. P. and Brar, J.S. (2005). The physic-chemical characteristics and fertility status of soil of Amritsar District of Punjab, J. Res. Punjab agric. Univ. 42 (1) 19-27.

Singh, S.K., Maneesh Kumar, R.P. Singh, J.S. Bohra, J.P. Srivastava. SS.P. Singh and Y.V. Singh (2018). Conjoint Application of Organic and Inorganic Sources of Nutrient on Yield, Nutrient Uptake and soil fertility under rice wheat systemin at Varanasi, Uttar Pradesh. Journal of the Indian society of soil science. (3) 287-294.

Sunny Abhishek Tigga, T. Thomas, A.A. David, N. Swaroop and P.S. Rao (2017), Assessment and characterization of soil in Sarguja district, Chhattisgarh, India, International Journal of Current Microbiology and Applied Sciences., 6(7) 223-229.

Tarun Kumar Kevat, Tapas Chowdhury, MC Bhambri, SB Gupta, Ravindra Soni and Dipika (2019). Changes in physicochemical properties of soil as influenced by conservation agriculture in rice based cropping system of Chhattisgarh IJFBS S; 6(1): 19-23.

Toth, S. J. and Prince, A. L. (1949). Estimation of cation exchange capacity 
and exchangeable $\mathrm{Ca}, \mathrm{K}$ and $\mathrm{Na}$ Content of soil flame photometer technique. Soil scince.67 439-445

Walkley, A. (1947). Critical examination of rapid method for determining organic carbon in soil, effect of variation in digestion condition and of inorganic soil constitutes. Soil science, 63,251-264.

Wilcox, L. V. (1950). Electrical conductivity, Amer. Water work assoc. J. 42 775-776.

\section{How to cite this article:}

Kavita Chandravanshi, Narendra Swaroop, and Tarence Thomas. 2020. Assessment and Characterization of Macronutrient in Soil of Kabeerdham District, Chhattisgarh, India. Int.J.Curr.Microbiol.App.Sci. 9(08): 2833-2841. doi: https://doi.org/10.20546/ijcmas.2020.908.318 